\title{
ORIGINAL RESEARCH \\ Burden of Disease, Injuries, and Risk Factors in the Kingdom of Saudi Arabia, $1990-2010$
}

\author{
Ziad A. Memish, MD; Sara Jaber, MD; Ali H. Mokdad, PhD, MD; \\ Mohammad A. AIMazroa, MD; Christopher J.L. Murray, MD; \\ Abdullah A. AI Rabeeah, MD; the Saudi Burden of Disease Collaborators
}

\begin{abstract}
Suggested citation for this article: Memish ZA, Jaber S, Mokdad AH, AlMazroa MA, Murray CJ, Al Rabeeah AA, et al. Burden of Disease, Injuries, and Risk Factors in the Kingdom of Saudi Arabia, 1990-2010. Prev Chronic Dis 2014;11:140176. DOI: http://dx.doi.org/10.5888/pcd11.140176.
\end{abstract}

\section{PEER REVIEWED}

\section{Abstract}

\section{Introduction}

We report the burden of disease and risk factors measured by causes of death, years of life lost attributable to premature mortality (YLLs), years of life lived with disability (YLDs), and disability-adjusted life years (DALYs) for 1990, 2005, and 2010 in the Kingdom of Saudi Arabia (KSA).

\section{Methods}

We used the Global Burden of Diseases 2010 (GBD 2010) methodology to estimate the country-level burden of disease in KSA. We used data from systematic reviews of the literature, household survey data, antenatal clinic surveillance data, reportable disease notifications, disease registries, hospital admissions data, outpatient visit data, population-based cancer registries, active screening data, and other administrative data.

\section{Results}

Noncommunicable diseases and road traffic injuries became the leading cause of death and disability in KSA in 2010. Elevated body mass index was the leading risk factor for disease $(7.02 \%$ for males and $4.61 \%$ for females in 2010). High glucose levels were the second leading disease risk factor for females $(3.28 \%)$ and third for males $(6.25 \%)$ in 2010 . Preterm birth complications were the main cause for DALYs in 1990; however, in 2010, the leading cause of DALYs for males was road traffic injuries $(12.40 \%)$ and for females it was major depressive disorder (7.88\%).

\section{Conclusion}

$\mathrm{KSA}$ is facing a rising burden of noncommunicable diseases and road traffic injuries as a result of rapid changes in behaviors. Our results demonstrate the need for major intervention to reduce these burdens and to engage other sectors of the government and the community in these efforts.

\section{Introduction}

The Kingdom of Saudi Arabia (KSA) made tremendous improvements in its health care systems in a short time because of extensive investments $(1,2)$. The Ministry of Health $(\mathrm{MOH})$ is responsible for $60 \%$ of the health care services, with the remaining $40 \%$ managed by numerous semipublic organizations and the private sector (3). In 2010, the MOH employed 250,000 personnel (including 31,516 physicians and 75,978 nurses), and it operated 249 hospitals with 34,000 beds (4).

KSA faces several health challenges that are unusual for a country with high income. The religious sites are visited by millions of pilgrims throughout the year, and a mass gathering occurs during Hajj (5). Although there are strict requirements for vaccination to avoid disease outbreaks during Hajj, the sheer number of visitors contributes to increased infectious disease burden (5). Moreover, illegal migration to KSA for work or Hajj adds to this burden because most illegal immigrants do not have the required vaccinations. In recent years and with improvements in infrastructure and health services, an emerging burden of noncommunicable diseases (NCDs) is unfolding; studies found high rates of obesity, diabetes, and high blood pressure (6-10). Moreover, with increased use of motor vehicles, the burden of road traffic injuries increased (11). 
The $\mathrm{MOH}$ is investing in reforming its health information systems and in May 2012 began a collaboration with the Institute for Health Metrics and Evaluation (IHME) to implement an integrated health information system within the next 5 years. The collaboration involves creating a database of the burden of disease, injuries, and risk factors for KSA at the national and local level. In this article, we report the national burden of disease in KSA for 1990 through 2010 based on the results of the Global Burden of Disease 2010 (GBD 2010) project (12).

\section{Methods}

The GBD 2010 was a systematic scientific effort to quantify the comparative magnitude of loss of health for 187 countries from 1990 to 2010. The GBD 2010 covered 291 diseases and injuries, 1,160 sequelae of these diseases and injuries, and 67 risk factors or clusters of risk factors for various diseases or injuries (12-18). GBD 2010 estimates the burden of disease and injury by age, sex, and country for 1990, 2005, and 2010 (8-14). Loss of health was assessed on the basis of a systemic analysis of all the available data by using the following metrics: mortality, causes of death, years of life lost attributable to premature mortality (YLLs), years of life lived with disability (YLDs), and disability-adjusted life years (DALYs).

DALYs provide a summary measure of premature mortality and time spent in less than ideal health (12). YLLs, YLDs, and DALYs measure loss of health in terms of time (12). DALYs are the sum of YLLs and YLDs (12). YLLs are the number of deaths attributed to a disease multiplied by the standard life expectancy at the age of death in years (12). YLD is the prevalence of each disease or injury sequela multiplied by the associated disability weight for that sequela and the duration until the person with the disease dies or the disease goes into remission (12).

\section{Mortality}

A detailed description of how age-specific mortality was estimated for each sex, country, and year is published elsewhere (15). Data on mortality come from various sources depending on the availability of data. For countries with abundant resources, information on deaths is from official vital registration systems (15). In low- and middle-income countries, multiple sources of data may be used in an attempt to achieve as complete all-cause mortality estimates as possible (12-18).

\section{Risk factors}

Sixty-seven risk factors or clusters of risk factors responsible for mortality, YLLs, YLDs, or DALYs were examined in GBD 2010. The attributable deaths or DALYs associated with each risk factor were assessed by using 4 components: 1) a database on risk factor-exposure from the published literature, 2) estimates of the prevalence of risk factor-exposure by country, age, and sex based on both published and unpublished sources using mostly Bayesian methods, 3) estimates of the relative risks for risk-disease pairs based on published and unpublished data, and 4) comparison of the current distribution of exposure to a counterfactual distribution called the theoretical minimum risk distribution (13) for each risk factor. Each risk factor or risk factor cluster was analyzed separately, such that the sum of attributable fractions for a disease or injury may be greater than $100 \%$. Uncertainty in the relative risks, exposure estimates, theoretical minimum risk distributions, and in the background outcome rates were considered in the final estimates.

IHME in collaboration with the KSA MOH developed a database of published and unpublished data sources to estimate the burden of disease for KSA. Key sources for this database included data from systematic reviews of the literature, household surveys, antenatal clinic surveillance, reportable disease notifications, disease registries, hospital admissions, outpatient visits, populationbased cancer registries, screening results, and other administrative sources. These data sources were used to estimate the disease and disability burden for 1990, 2005, and 2010.

\section{Results}

From 1990 through 2010, there was a decline in age-specific mortality in KSA (Figure 1). The greatest reductions in all-cause mortality were among males aged less than 1 year $(51 \%)$. Men aged 80 years or older had an increase in mortality (14\%). During the same time, life expectancy increased from 72.5 to 75.0 for men and from 76.3 to 79.9 for women (Figure 2). During the same time, healthy life expectancy increased from 61.8 to 63.9 for men and from 63.5 to 66.6 for women. Infant mortality declined from 23.8 per 1,000 to 11.9 per 1,000 , and maternal mortality ratios declined from 30.0 to 15.0 per 100,000 live births.

\footnotetext{
The opinions expressed by authors contributing to this journal do not necessarily reflect the opinions of the U.S. Department of Health and Human Services, the Public Health Service, the Centers for Disease Control and Prevention, or the authors' affiliated institutions.
} 


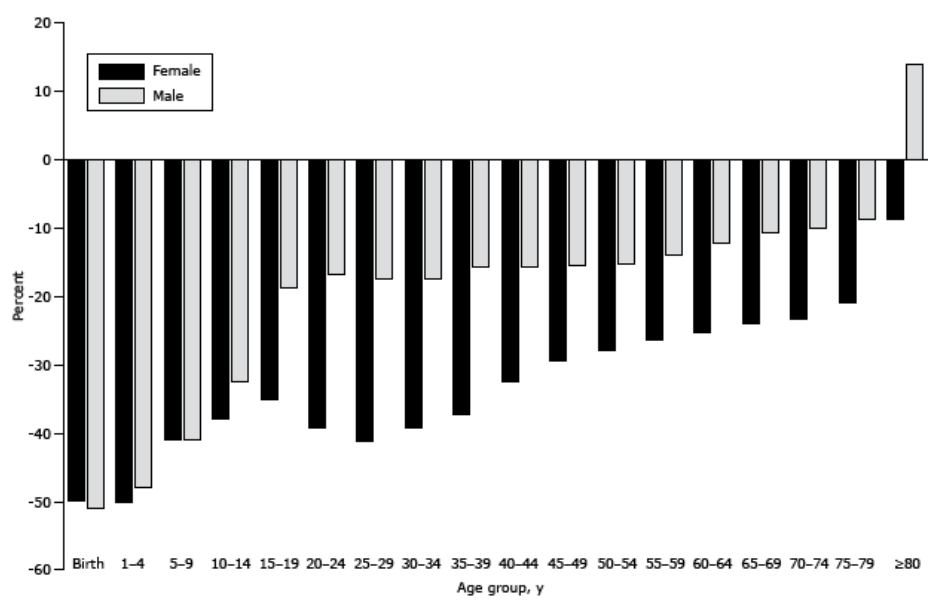

Figure 1. Percentage decline in mortality from 1990 to 2010, by sex, Kingdom of Saudi Arabia.

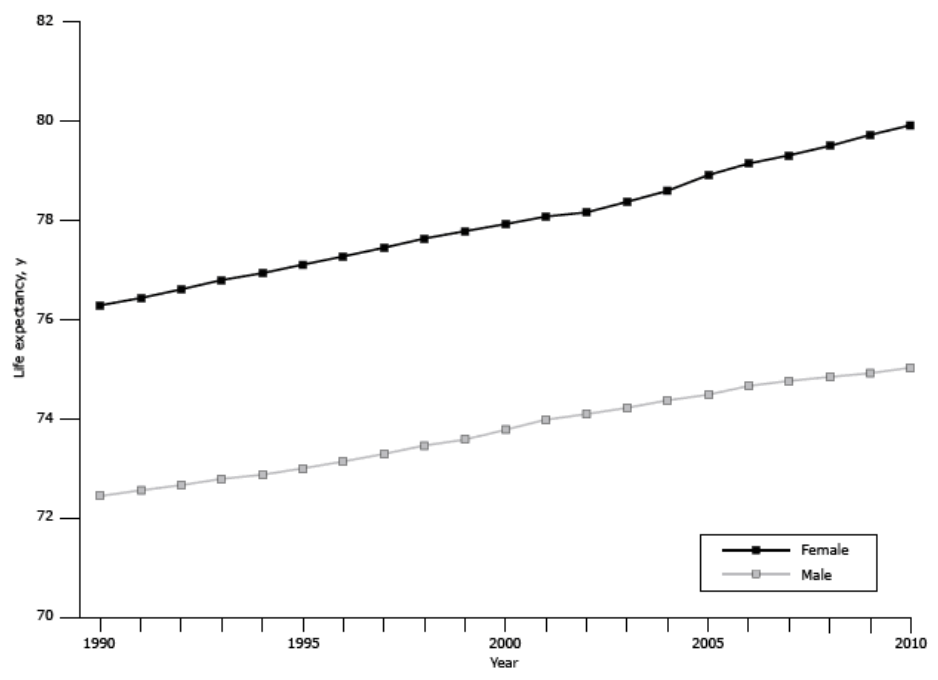

Figure 2. Life expectancy at birth by sex, Kingdom of Saudi Arabia, 1990-2010.

The main cause of death in 1990 was ischemic heart disease (IHD), accounting for $16.04 \%$ of total mortality (Table 1). Road traffic injuries were the third leading cause of death in 2010, accounting for $11.75 \%$ of total mortality. The patterns in causes of death were different for males and females throughout the study period.

In 2010, the main causes of DALYS in KSA were major depressive disorder, road traffic injuries, IHD, and diabetes (Table 2). This change in leading causes is a major shift from preterm birth complications in 1990 (12.17\%). Road traffic injuries were mostly concentrated in age groups from 15 through 54 years (Figure 3). Mental disorders were concentrated mostly in age groups from 15 through 44 years.

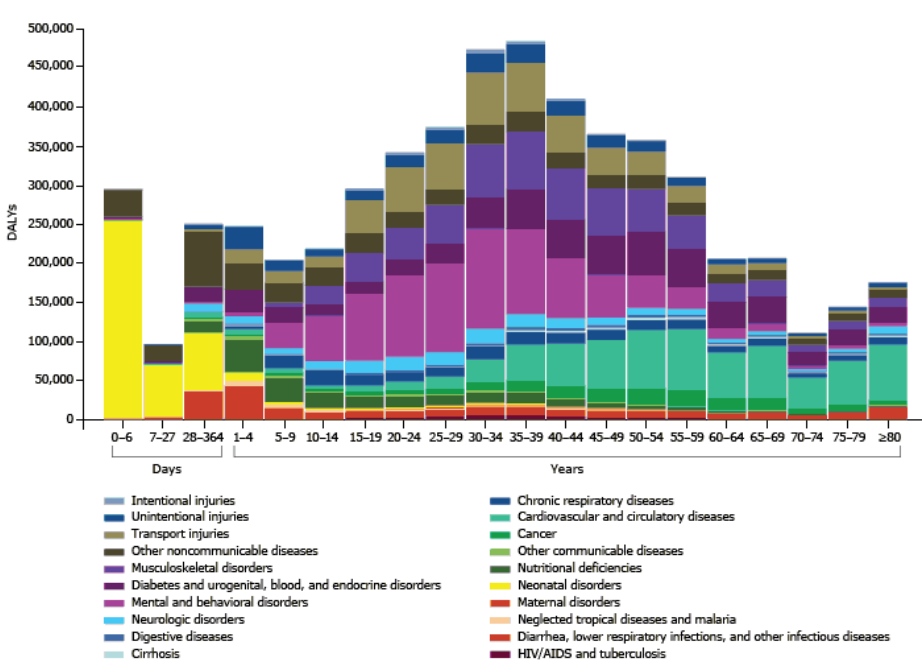

Figure 3. Disability-adjusted life years (DALYs) by cause and age, Kingdom of Saudi Arabia, 2010.

Metabolic risk factors are the main causes of DALYs in KSA for 1990, 2005, and 2010 (Table 3). For 2005 and 2010, elevated body mass index (BMI) and dietary risks continued to be the leading disease risk factors (for BMI, $10.20 \%$ in 2005 and $11.64 \%$ in 2010; for dietary risks, $9.25 \%$ in 2005 and $9.68 \%$ in 2010 ).

In 2010, DALYs from NCDs were highest among older age groups and started increasing after age 40 years (Figure 3 ). Mental and behavioral disorders were highest among those aged 20 through 39 years. Musculoskeletal disorders were high among those aged 30 through 44 years.

\section{Discussion}

Our study shows that KSA is facing a rising burden of road traffic accidents (RTAs), major depressive disorder, and NCDs. These findings are a clear indication of KSA's success in controlling infectious diseases and reducing their prevalence. The rise of RTAs and NCDs are a clear warning of the need for immediate intervention. The major challenge ahead for KSA is reducing the burden of chronic diseases and their risk factors. As the country's population ages and grows, NCDs will pose a major challenge to KSA even with its wealth and resources.

The opinions expressed by authors contributing to this journal do not necessarily reflect the opinions of the U.S. Department of Health and Human Services, the Public Health Service, the Centers for Disease Control and Prevention, or the authors' affiliated institutions. 
Our findings on the huge burden of NCDs in KSA are similar to those we observed in the GBD 2010 results for other Gulf countries. NCDs are becoming a major burden in the region and in the Arab world (19). The rapid change in the burden profile in the region is alarming. Diabetes, obesity, high blood pressure, cancers, and cardiovascular diseases are putting a huge toll on the health care systems and on society. This transition needs a planned intervention to control and prevent the future burden of disease. Most governments in the region have not given attention to NCDs as they have given or are giving to infectious disease. A new culture of health care in KSA and the region should be a priority.

Our findings on DALYs in KSA deserve special attention. First, there are huge variations in the burden by age. Second, it is clear that mental health is becoming a major challenge for KSA. This could be due to societal changes and a move away from tradition where family support was always available. Third, it is clear that what is killing Saudis is different from what is ailing them: mental and musculoskeletal disorders are becoming a major challenge for the Saudi health system but not a major cause of death. Finally, NCDs are the main challenge because they are a major cause of disability and death.

Despite the growth of NCDs and RTAs, KSA is a unique country where outbreaks of infectious disease are always a threat because of the large number of pilgrims visiting the Kingdom throughout each year and especially during the Hajj season. This threat requires lots of effort and resources for infectious disease control and prevention. Conditions surrounding the Hajj such as extended stays in a single geographic area, physical exhaustion, extreme heat, and crowded accommodations usually lead to disease transmission, especially of airborne agents (5). The novel beta coronavirus called $\mathrm{HCoV}$-EMC that infected a Saudi patient in June 2012 is a reminder that outbreaks will continue to be a major challenge (20).

The changing patterns of disease in KSA have forced the $\mathrm{MOH}$ to adapt its mission and operation to deliver timely solutions for emerging challenges. These challenges include issues of workforce development, financing, insurance, accessibility, and use of electronic health resources (1). The $\mathrm{MOH}$ implemented several new programs to control and prevent disease. A compulsory vaccination program, which started in the 1980s and has been updated since, has led to a substantial drop in mortality among those aged less than 5 years, from 250 per 1,000 live births in 1960 to 26 per 1,000 live births in 2005 (21). An innovative 5-year project was launched in 2012 in collaboration with IHME to create an in- tegrated tracking system to monitor the health status of Saudi citizens and determine health policy priorities. The project includes determining the burden of disease and risk factors at the local level.

The changes in lifestyle habits because of the recent economic growth are troubling. The prevalence of physical activity is low in the Kingdom (22). The hot weather and increased urbanization are not ideal for encouraging or promoting physical activities. Moreover, poor dietary behaviors are common in KSA (23). Obesity is a major problem in the country with a prevalence of $42.4 \%$ among males and $31.8 \%$ among females (24). As a result, KSA has a high prevalence of metabolic syndrome of $39.3 \%$ (25) and coronary artery diseases of $5.5 \%$ (26). Smoking prevalence in KSA ranges from $1.4 \%$ among females aged 15 through 64 years to $24.2 \%$ among males aged 15 through 64 years $(27,28)$. The prevalence differs among the age groups, with males more likely than females to smoke (median for males, 26.5\%, and for females, 9\%) (27). Another important issue is water-pipe smoking (known as shisha), which seems to be highly prevalent among teenagers (29).

In September 2012, the $\mathrm{MOH}$ in KSA in collaboration with the World Health Organization (WHO) regional office for the Eastern Mediterranean (EMRO) organized an international conference to address the topic of NCDs in the area (30). The conference released the Riyadh Declaration that included 10 recommendations to combat NCDs at the regional level (Appendix). The MOH has worked with WHO/EMRO, and the declaration was adopted by EMRO during the regional committee meeting in October 2012. These recommendations will have a major impact on health in KSA and the region.

RTAs are now a major burden in KSA because of nonadherence to traffic and safety laws. The patterns of driving and traffic regulations changed from 1990 to 2010 . RTAs have a major impact on the working population in terms of lost productivity (11). The $\mathrm{MOH}$ in collaboration with the Ministry of Interior launched a road safety program called Saher in 2009 (31). Saher is an automated system that was developed to manage traffic via electronic systems in major cities in Saudi Arabia (31). This newly established system uses a digital camera network connected to the $\mathrm{Na}$ tional Information Center to track any violations and to control traffic (31). However, data on its long-term effects on accidents and deaths are not yet available. Other efforts to reduce RTAs should focus on police enforcement of traffic laws. RTAs would be much lower if the police were to ensure that drivers have a license and that all vehicle occupants are wearing seat belts.

\footnotetext{
The opinions expressed by authors contributing to this journal do not necessarily reflect the opinions of the U.S. Department of Health and Human Services, the Public Health Service, the Centers for Disease Control and Prevention, or the authors' affiliated institutions.
} 
Societal mores play an important role in health promotion. Individual well-being is directly related to the strength of the social relationships and support that a person receives (32). The problems that the Saudi health system is facing require multi-sectorial interventions with roles and responsibilities for many players. Perhaps an important role should be played by the religious community. Religious institutions can be a source of social support by stressing values that influence health-related behavior (33). Faith organizations can influence the health education, health promotion, and positive health outcomes of the members of their faith community (33).

KSA is a country with deep cultural roots and traditions, including involvement in sports and physical activity. KSA needs role models who can encourage people to improve their diet and increase their level of physical activity.

Our study has limitations. We used the most recent data on the prevalence of NCD risk factors from the 2005 WHO STEPwise Approach to NCD Surveillance and the 2008 World Health Survey $(28,34)$ to report the burden in 2010 . It is possible that the prevalence has changed since then. In addition, mortality data in KSA may be underreported especially for women. However, we applied our standard techniques to deal with garbage coding and underreporting to produce our estimates $(18,19)$. Moreover, we incorporated a wealth of information and data into our work.

Our findings demonstrate the need for developing and implementing programs to reduce health risk factors in KSA. Such programs need to be locally developed and adopted because many programs described in the literature may not succeed in KSA. Programs to promote physical activity especially among women need to be culturally sensitive and appropriate for the harsh weather in KSA. Many programs will require political will and legislation to succeed. Perhaps gyms could be built where physical activity programs would be available and supervised by medical staff. Moreover, police must enforce driving laws, especially those related to speed, safety, and driver's age. Finally, religious and community leaders should have a role in in all mass campaigns to improve health.

\section{Acknowledgments}

This study was financially supported by a grant from the MOH of the KSA. The Saudi Burden of Disease Collaborators (working group) consisted of Charbel El Bcheraoui, PhD, MSc; Farah Daoud, BSc; Marwa Tuffaha, MD; Tasha Murphy, PhD; Diego
Gonzalez-Medina, BA; Charles Atkinson, BSc; Lee Richardson, BSc; Matthew Coates, AB; Rafael Lozano, PhD; Mohsen Naghavi, PhD; Mohammed Basulaiman, MD; Mohammad Al Saeedi, MD; and Mohammed Zamakhshary, MD.

\section{Author Information}

Corresponding Author: Ziad A. Memish, MD, Ministry of Health of the Kingdom of Saudi Arabia, Assadah, Al Murabba Riyadh 12613, Saudi Arabia. Telephone: +9661-2124052. Fax: +96612125052. E-mail: zmemish@yahoo.com.

Author Affiliations: Sara Jaber, Ali H. Mokdad, Christopher J.L. Murray, Institute for Health Metrics and Evaluation, University of Washington, Seattle, Washington, USA; Mohammad A. AlMazroa, Abdullah A. Al Rabeeah, Ministry of Health of the Kingdom of Saudi Arabia, Assadah, Al Murabba Riyadh, Saudi Arabia.

\section{References}

1. Almalki M, Fitzgerald G, Clark M. Health care system in Saudi Arabia: an overview. East Mediterr Health J 2011; 17(10):784-93.

2. Kingdom of Saudi Arabia healthcare overview. Colliers International; 2012. http://www.colliers.com/ /media/files/ emea/emea/research/speciality/2012q1-saudi-arabiahealthcare-overview.ashx. Accessed March 27, 2014.

3. Alyemini MR. Five year program to transform healthcare delivery in Saudi Arabia. http://www.salud-e.cl/wp-content/ uploads $/ 2013 / 08 /$ saudi+arabia+e-health+strategy.pdf. Accessed March 27, 2014.

4. Balkhair A. Kingdom of Saudi Arabia, The National eHealth Program. http://www.itu.int/ITU-D/cyb/events/2012/e-health/ Nat_eH_Dev/Session\%204/KS A-MOH-PresentationSaudiArabia\%20FINAL.pdf. Accessed March 27, 2014.

5. Ahmed QA, Arabi YM, Memish ZA. Health risks at the Hajj. Lancet 2006;367(9515):1008-15.

6. Al-Nozha MM, Al-Maatouq MA, Al-Mazrou YY, Al-Harthi SS, Arafah MR, Khalil MZ, et al. Diabetes mellitus in Saudi Arabia. Saudi Med J 2004;25(11):1603-10.

7. Al-Nozha MM, Abdullah M, Arafah MR, Khalil MZ, Khan NB, Al-Mazrou YY. Hypertension in Saudi Arabia. Saudi Med J 2007;28(1):77-84.

8. Saeed AA, Al-Hamdan NA, Bahnassy AA, Abdalla AM, Abbas MAF, Abuzaid LZ. Prevalence, awareness, treatment, and control of hypertension among Saudi adult population: a national survey. Int J Hypertens 2011;2011:174135.

\footnotetext{
The opinions expressed by authors contributing to this journal do not necessarily reflect the opinions of the U.S. Department of Health and Human Services, the Public Health Service, the Centers for Disease Control and Prevention, or the authors' affiliated institutions.
} 
9. Fatani HH, Mira SA, el-Zubier AG. Prevalence of diabetes mellitus in rural Saudi Arabia. Diabetes Care 1987; 10(2):180-3.

10. Al-Nozha MM, Al-Maatouq MA, Al-Mazrou YY, Al-Harthi SS, Arafah MR, Khalil MZ, et al. Diabetes mellitus in Saudi Arabia. Saudi Med J 2004;25(11):1603-10.

11. Elshinnawey MA, Fiala LE, Abbas MA, Othman N. Road traffic injuries in Saudi Arabia, and its impact on the working population. J Egypt Public Health Assoc 2008;83(1-2):1-14.

12. Murray CJL, Ezzati M, Flaxman AD, Lim S, Lozano R, Michaud C, et al. GBD 2010: design, definitions, and metrics. Lancet 2012;380(9859):2063-6.

13. Lim SS, Vos T, Flaxman AD, Danaei G, Shibuya K, AdairRohani $\mathrm{H}$, et al. A comparative risk assessment of burden of disease and injury attributable to 67 risk factors and risk factor clusters in 21 regions, 1990-2010: a systematic analysis for the Global Burden of Disease Study 2010. Lancet 2012; 380(9859):2224-60. Errata in Lancet 2013;381(9874):1276; Lancet 2013;381(9867):628.

14. Lozano R, Naghavi M, Foreman K, Lim S, Shibuya K, Aboyans V, et al. Global and regional mortality from 235 causes of death for 20 age groups in 1990 and 2010: a systematic analysis for the Global Burden of Disease Study 2010. Lancet 2012;380(9859):2095-128. Erratum in Lancet 2013;381(9867):628.

15. Wang H, Dwyer-Lindgren L, Lofgren KT, Rajaratnam JK, Marcus JR, Levin-Rector A, et al. Age-specific and sexspecific mortality in 187 countries, 1970-2010: a systematic analysis for the Global Burden of Disease Study 2010. Lancet 2012;380(9859):2071-94.

16. Murray CJL, Vos T, Lozano R, Naghavi M, Flaxman AD, Michaud C, et al. Disability-adjusted life years (DALYs) for 291 diseases and injuries in 21 regions, 1990-2010: a systematic analysis for the Global Burden of Disease Study 2010. Lancet 2012;380(9859):2197-223. Erratum in Lancet 2013;381(9867):628.

17. Salomon JA, Vos T, Hogan DR, Gagnon M, Naghavi M, Mokdad A, et al. Common values in assessing health outcomes from disease and injury: disability weights measurement study for the Global Burden of Disease Study 2010. Lancet 2012; 380(9859):2129-43. Erratum in Lancet 2013;381(9867):628.

18. Salomon JA, Wang H, Freeman MK, Vos T, Flaxman AD, Lopez AD, et al. Healthy life expectancy for 187 countries, 1990-2010: a systematic analysis for the Global Burden Disease Study 2010. Lancet 2012;380(9859):2144-62. Erratum in Lancet 2013;381(9867):628.
19. Mokdad AH, Jaber S, Aziz MIA, AlBuhairan F, AlGhaithi A, AlHamad NM, et al. The state of health in the Arab world, 1990-2010: an analysis of the burden of diseases, injuries, and risk factors. Lancet 2014;383(9914):309-20.

20. Anderson LJ, Baric RS. Emerging human coronaviruses disease potential and preparedness. N Engl J Med 2012; 367(19):1850-2.

21. Aldossary A, While A, Barriball L. Health care and nursing in Saudi Arabia. Int Nurs Rev 2008;55(1):125-8.

22. Al-Nozha MM, Al-Hazzaa HM, Arafah MR, Al-Khadra A, AlMazrou YY, Al-Maatouq MA, et al. Prevalence of physical activity and inactivity among Saudis aged $30-70$ years. A population-based cross-sectional study. Saudi Med J 2007; 28(4):559-68.

23. Al-Hazzaa HM, Abahussain NA, Al-Sobayel HI, Qahwaji DM, Musaiger AO. Physical activity, sedentary behaviors and dietary habits among Saudi adolescents relative to age, gender and region. Int J Behav Nutr Phys Act 2011;8(1):140.

24. Al-Nozha MM, Al-Mazrou YY, Al-Maatouq MA, Arafah MR, Khalil MZ, Khan NB, et al. Obesity in Saudi Arabia. Saudi Med J 2005;26(5):824-9.

25. Al-Nozha M, Al-Khadra A, Arafah MR, Al-Maatouq MA, Khalil MZ, Khan NB, et al. Metabolic syndrome in Saudi Arabia. Saudi Med J 2005;26(12):1918-25.

26. Al-Nozha MM, Arafah MR, Al-Mazrou YY, Al-Maatouq MA, Khan NB, Khalil MZ, et al. Coronary artery disease in Saudi Arabia. Saudi Med J 2004;25(9):1165-71.

27. Bassiony MM. Smoking in Saudi Arabia. Saudi Med J 2009; 30(7):876-81.

28. WHO STEPwise approach to NCD surveillance. Countryspecific standard report. Saudi Arabia 2005. Ministry of Health, Kingdom of Saudi Arabia, World Health Organization, E M R O. htt p:// w w w . who.int/chp/steps/ 2005_SaudiArabia_STEPS_Report_EN.pdf. Accessed March $27,2014$.

29. Al Moamary MS, Al Ghobain MA, Al Shehri SN, Alfayez AI, Gasmelseed AY, Al-Hajjaj MS. The prevalence and characteristics of water-pipe smoking among high school students in Saudi Arabia. J Infect Public Health 2012; 5(2):159-68.

30. International conference on healthy lifestyles and noncommunicable diseases in the Arab world and the Middle East, Riyadh, 10-12 September 2012. WHO Regional Office for the Eastern Mediterranean. http://www.emro.who.int/ noncommunicable-diseases/ncd-events/riyadh-conferenceseptember-2012.html. Accessed March 27, 2014.

\footnotetext{
The opinions expressed by authors contributing to this journal do not necessarily reflect the opinions of the U.S. Department of Health and Human Services, the Public Health Service, the Centers for Disease Control and Prevention, or the authors' affiliated institutions.
} 
31. Saher: an automated traffic control and management system. Ministry of Interior, Kingdom of Saudi Arabia. http:// www.moi.gov.sa/wps/portal/trafficriyadh/!ut/p/b1/

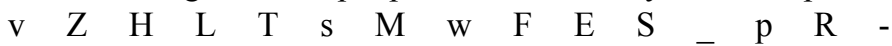
API4dJ166Tv0IcoixCNQblEWFIrXpBvH9BLWwACpYIGZ3 pTN37oNksqVUclExWTHyQPI8vkxP4_N0nMf9W53FY6177 evAqLW9gN8AvNLXFKALsF2ANbCRa6pQuwB4F4fiLgxK $\begin{array}{llllllllll}M & P & z & O & j & w & t & S & f & -\end{array}$ 3XXMNzOiDpkrW35X_nf_Gn3UzuSf5pzBPwcWbIoYLvOx OkKQpIdgZsNyRmHaOwtoGPfWrbGJgw4gzgpggNjVoZRM ebUrr3UT9HfPPJU4fLq3bueNiRQ96bRXXyk79Sq9UrCesmj

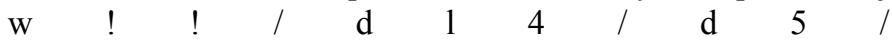
L01DU01KSWdrbUEhIS9JRFJBQUlpQ2dBek15cXchLzRKQ2 1Eb01OdEJqdEJIZmxDRUEhL1o3XzVDUENJOE0zMUdHU D Y w S U U w M D Q 3 Q 0 s x M D g 2 L z A ! / ?WCM_PORTLET $=$ PC_Z7_5CPCI8M31GGP60IE0047CK10 860n8232_WCM\&WCM_GLOBAL_CONTEXT $=/ \mathrm{wps} / \mathrm{wcm} /$ connect/Traffic/Traffic+Riyadh/Main/saher/. Accessed August 18, 2014.

32. Berkman LF. The role of social relations in health promotion. Psychosom Med 1995;57(3):245-54.

33. Toni-Uebari TK, Inusa BPD. The role of religious leaders and faith organizations in haemoglobinopathies: a review. BMC Blood Disord 2009;9:6.

34. The World Health Survey (WHS). The Executive Board of Health Ministers' Council for GCC States. http://sgh.org.sa/enus/studiesandresearch/worldhealthsurvey.aspx. Accessed August 18, 2014.

The opinions expressed by authors contributing to this journal do not necessarily reflect the opinions of the U.S. Department of Health and Human Services, the Public Health Service, the Centers for Disease Control and Prevention, or the authors' affiliated institutions. 


\section{Tables}

Table 1. Leading Causes of Death by Sex, Kingdom of Saudi Arabia, 1990, 2005, and 2010

\begin{tabular}{|c|c|c|c|c|c|c|c|c|c|}
\hline \multirow[b]{2}{*}{ Rank } & \multicolumn{3}{|c|}{1990} & \multicolumn{3}{|c|}{2005} & \multicolumn{3}{|c|}{2010} \\
\hline & Male (\%) & Female (\%) & Total (\%) & Male (\%) & Female (\%) & Total (\%) & Male (\%) & Female (\%) & Total (\%) \\
\hline 1 & $\begin{array}{l}\text { Ischemic heart } \\
\text { disease } \\
(17.19 \%)\end{array}$ & $\begin{array}{l}\text { Cerebrovascular } \\
\text { disease } \\
(14.24 \%)\end{array}$ & $\begin{array}{l}\text { Ischemic heart } \\
\text { disease } \\
(16.04 \%)\end{array}$ & $\begin{array}{l}\text { Ischemic heart } \\
\text { disease } \\
(19.56 \%)\end{array}$ & $\begin{array}{l}\text { Ischemic heart } \\
\text { disease } \\
\text { (16.84\%) }\end{array}$ & $\begin{array}{l}\text { Ischemic heart } \\
\text { disease } \\
(18.65 \%)\end{array}$ & $\begin{array}{l}\text { Ischemic heart } \\
\text { disease } \\
(19.25 \%)\end{array}$ & $\begin{array}{l}\text { Ischemic heart } \\
\text { disease } \\
(17.94 \%)\end{array}$ & $\begin{array}{l}\text { Ischemic heart } \\
\text { disease } \\
(18.77 \%)\end{array}$ \\
\hline 2 & $\begin{array}{l}\text { Road traffic } \\
\text { injury (13.64\%) }\end{array}$ & $\begin{array}{l}\text { Ischemic heart } \\
\text { disease } \\
(14.20 \%)\end{array}$ & $\begin{array}{l}\text { Cerebrovascular } \\
\text { disease } \\
(11.39 \%)\end{array}$ & $\begin{array}{l}\text { Road traffic } \\
\text { injury (15.08) }\end{array}$ & $\begin{array}{l}\text { Cerebrovascular } \\
\text { disease } \\
(15.35 \%)\end{array}$ & $\begin{array}{l}\text { Cerebrovascular } \\
\text { disease } \\
(12.81 \%)\end{array}$ & $\begin{array}{l}\text { Road traffic } \\
\text { injury (16.08\%) }\end{array}$ & $\begin{array}{l}\text { Cerebrovascular } \\
\text { disease } \\
(16.93 \%)\end{array}$ & $\begin{array}{l}\text { Cerebrovascular } \\
\text { disease } \\
(13.20 \%)\end{array}$ \\
\hline 3 & $\begin{array}{l}\text { Cerebrovascular } \\
\text { disease }(9.62 \%)\end{array}$ & $\begin{array}{l}\text { Preterm birth } \\
\text { complications } \\
(11.24 \%)\end{array}$ & $\begin{array}{l}\text { Preterm birth } \\
\text { complications } \\
(10.12 \%)\end{array}$ & $\begin{array}{l}\text { Cerebrovascular } \\
\text { disease } \\
(11.54 \%)\end{array}$ & $\begin{array}{l}\text { Preterm birth } \\
\text { complications } \\
\text { (6.91\%) }\end{array}$ & $\begin{array}{l}\text { Road traffic } \\
\text { injury (11.71\%) }\end{array}$ & $\begin{array}{l}\text { Cerebrovascular } \\
\text { disease } \\
(11.05 \%)\end{array}$ & $\begin{array}{l}\text { Lower respiratory } \\
\text { infections } \\
(5.97 \%)\end{array}$ & $\begin{array}{l}\text { Road traffic } \\
\text { injury (11.75\%) }\end{array}$ \\
\hline 4 & $\begin{array}{l}\text { Preterm birth } \\
\text { complications } \\
(9.43 \%)\end{array}$ & $\begin{array}{l}\text { Congenital } \\
\text { anomalies } \\
(6.89 \%)\end{array}$ & $\begin{array}{l}\text { Road traffic } \\
\text { injury }(9.99 \%)\end{array}$ & $\begin{array}{l}\text { Lower respiratory } \\
\text { infections } \\
(5.12 \%)\end{array}$ & $\begin{array}{l}\text { Lower respiratory } \\
\text { infections } \\
(5.39 \%)\end{array}$ & $\begin{array}{l}\text { Preterm birth } \\
\text { complications } \\
(5.24 \%)\end{array}$ & $\begin{array}{l}\text { Lower respiratory } \\
\text { infections } \\
(5.01 \%) \\
\end{array}$ & $\begin{array}{l}\text { Preterm birth } \\
\text { complications } \\
(5.05 \%)\end{array}$ & $\begin{array}{l}\text { Lower respiratory } \\
\text { infections } \\
(5.36 \%)\end{array}$ \\
\hline 5 & $\begin{array}{l}\text { Lower respiratory } \\
\text { infections } \\
(5.73 \%) \\
\end{array}$ & $\begin{array}{l}\text { Lower respiratory } \\
\text { infections } \\
(6.52 \%)\end{array}$ & $\begin{array}{l}\text { Lower respiratory } \\
\text { infections } \\
(6.03 \%)\end{array}$ & $\begin{array}{l}\text { Preterm birth } \\
\text { complications } \\
(4.40 \%)\end{array}$ & \begin{tabular}{|l} 
Road traffic \\
injury (5.02\%)
\end{tabular} & $\begin{array}{l}\text { Lower respiratory } \\
\text { infections } \\
(5.21 \%)\end{array}$ & $\begin{array}{l}\text { Chronic kidney } \\
\text { diseases (3.90\%) }\end{array}$ & $\begin{array}{l}\text { Road traffic } \\
\text { injury }(4.22 \%)\end{array}$ & $\begin{array}{l}\text { Preterm birth } \\
\text { complications } \\
(4.11 \%)\end{array}$ \\
\hline 6 & $\begin{array}{l}\text { Congenital } \\
\text { anomalies } \\
(4.46 \%)\end{array}$ & $\begin{array}{l}\text { Road traffic } \\
\text { Injury }(4.11 \%)\end{array}$ & $\begin{array}{l}\text { Congenital } \\
\text { anomalies } \\
(5.39 \%)\end{array}$ & $\begin{array}{l}\text { Chronic kidney } \\
\text { diseases (3.50\%) }\end{array}$ & $\begin{array}{l}\text { Congenital } \\
\text { anomalies } \\
(4.41 \%)\end{array}$ & $\begin{array}{l}\text { Chronic kidney } \\
\text { diseases (3.52\%) }\end{array}$ & $\begin{array}{l}\text { Diabetes mellitus } \\
(3.65 \%)\end{array}$ & $\begin{array}{l}\text { Chronic kidney } \\
\text { diseases (4.15\%) }\end{array}$ & $\begin{array}{l}\text { Chronic kidney } \\
\text { diseases (3.99\%) }\end{array}$ \\
\hline 7 & $\begin{array}{l}\text { Hypertensive } \\
\text { heart disease } \\
(1.90 \%)\end{array}$ & $\begin{array}{l}\text { Diarrheal } \\
\text { diseases (2.82\%) }\end{array}$ & $\begin{array}{l}\text { Diarrheal } \\
\text { diseases (2.22\%) }\end{array}$ & $\begin{array}{l}\text { Diabetes mellitus } \\
(3.24 \%)\end{array}$ & $\begin{array}{l}\text { Chronic kidney } \\
\text { diseases (3.55\%) }\end{array}$ & \begin{tabular}{|l} 
Diabetes mellitus \\
$(3.27 \%)$
\end{tabular} & $\begin{array}{l}\text { Preterm birth } \\
\text { complications } \\
(3.56 \%)\end{array}$ & $\begin{array}{l}\text { Diabetes mellitus } \\
(3.79 \%)\end{array}$ & $\begin{array}{l}\text { Diabetes mellitus } \\
(3.70 \%)\end{array}$ \\
\hline 8 & $\begin{array}{l}\text { Neonatal } \\
\text { encephalopathy } \\
(1.90 \%)\end{array}$ & $\begin{array}{l}\text { Neonatal } \\
\text { encephalopathy } \\
(2.32 \%)\end{array}$ & $\begin{array}{l}\text { Neonatal } \\
\text { encephalopathy } \\
(2.06 \%)\end{array}$ & $\begin{array}{l}\text { Hypertensive } \\
\text { heart disease } \\
(2.42 \%)\end{array}$ & $\begin{array}{l}\text { Diabetes mellitus } \\
(3.34 \%)\end{array}$ & $\begin{array}{l}\text { Congenital } \\
\text { anomalies } \\
(3.06 \%)\end{array}$ & $\begin{array}{l}\text { Hypertensive } \\
\text { heart disease } \\
(2.37 \%)\end{array}$ & $\begin{array}{l}\text { Congenital } \\
\text { anomalies } \\
(3.04 \%)\end{array}$ & $\begin{array}{l}\text { Hypertensive } \\
\text { heart disease } \\
(2.37 \%)\end{array}$ \\
\hline 9 & $\begin{array}{l}\text { Diarrheal } \\
\text { diseases (1.84\%) }\end{array}$ & $\begin{array}{l}\text { Sepsis and other } \\
\text { infectious } \\
\text { disorders of } \\
\text { newborn (1.97\%) }\end{array}$ & $\begin{array}{l}\text { Hypertensive } \\
\text { heart disease } \\
(1.88 \%)\end{array}$ & $\begin{array}{l}\text { Congenital } \\
\text { anomalies } \\
(2.39 \%)\end{array}$ & $\begin{array}{l}\text { Other } \\
\text { cardiovascular } \\
\text { and circulatory } \\
\text { diseases (2.40\%) }\end{array}$ & $\begin{array}{l}\text { Hypertensive } \\
\text { heart disease } \\
(2.37 \%)\end{array}$ & $\begin{array}{l}\text { Congenital } \\
\text { anomalies } \\
(1.91 \%)\end{array}$ & $\begin{array}{l}\text { Other } \\
\text { cardiovascular } \\
\text { and circulatory } \\
\text { diseases (2.60\%) }\end{array}$ & $\begin{array}{l}\text { Congenital } \\
\text { anomalies } \\
(2.32 \%)\end{array}$ \\
\hline
\end{tabular}

The opinions expressed by authors contributing to this journal do not necessarily reflect the opinions of the U.S. Department of Health and Human Services, the Public Health Service, the Centers for Disease Control and Prevention, or the authors' affiliated institutions.

8 Centers for Disease Control and Prevention • www.cdc.gov/pcd/issues/2014/14_0176.htm 


\section{PREVENTING CHRONIC DISEASE}

(continued)

Table 1. Leading Causes of Death by Sex, Kingdom of Saudi Arabia, 1990, 2005, and 2010

\begin{tabular}{|c|c|c|c|c|c|c|c|c|c|}
\hline \multirow[b]{2}{*}{ Rank } & \multicolumn{3}{|c|}{1990} & \multicolumn{3}{|c|}{2005} & \multicolumn{3}{|c|}{2010} \\
\hline & Male (\%) & Female (\%) & Total (\%) & Male (\%) & Female (\%) & Total (\%) & Male (\%) & Female (\%) & Total (\%) \\
\hline 10 & $\begin{array}{l}\text { Chronic } \\
\text { obstructive } \\
\text { pulmonary } \\
\text { disease }(1.75 \%)\end{array}$ & $\begin{array}{l}\text { Other } \\
\text { cardiovascular } \\
\text { and circulatory } \\
\text { diseases }(1.95 \%)\end{array}$ & $\begin{array}{l}\text { Chronic } \\
\text { obstructive } \\
\text { pulmonary } \\
\text { disease }(1.73 \%)\end{array}$ & $\begin{array}{l}\text { Other } \\
\text { cardiovascular } \\
\text { and circulatory } \\
\text { diseases (1.69\%) }\end{array}$ & $\begin{array}{l}\text { Hypertensive } \\
\text { heart disease } \\
(2.28 \%)\end{array}$ & $\begin{array}{l}\text { Other } \\
\text { cardiovascular } \\
\text { and circulatory } \\
\text { diseases }(1.93 \%)\end{array}$ & $\begin{array}{l}\text { Other } \\
\text { cardiovascular } \\
\text { and circulatory } \\
\text { diseases (1.64\%) }\end{array}$ & $\begin{array}{l}\text { Hypertensive } \\
\text { heart disease } \\
(2.38 \%)\end{array}$ & $\begin{array}{l}\text { Other } \\
\text { cardiovascular } \\
\text { and circulatory } \\
\text { diseases }(1.99 \%)\end{array}$ \\
\hline
\end{tabular}


Table 2. Leading Causes of Disability-Adjusted Life Years by Sex, Kingdom of Saudi Arabia, 1990, 2005, and 2010

\begin{tabular}{|c|c|c|c|c|c|c|c|c|c|}
\hline \multirow[b]{2}{*}{ Rank } & \multicolumn{3}{|c|}{1990} & \multicolumn{3}{|c|}{2005} & \multicolumn{3}{|c|}{2010} \\
\hline & Male (\%) & Female (\%) & Total (\%) & Male (\%) & Female (\%) & Total (\%) & Male (\%) & Female (\%) & Total (\%) \\
\hline 1 & $\begin{array}{l}\text { Preterm birth } \\
\text { complications } \\
(12.04 \%)\end{array}$ & $\begin{array}{l}\text { Preterm birth } \\
\text { complications } \\
(12.35 \%)\end{array}$ & $\begin{array}{l}\text { Preterm birth } \\
\text { complications } \\
(12.17 \%)\end{array}$ & $\begin{array}{l}\text { Road traffic } \\
\text { injury }(12.00 \%)\end{array}$ & $\begin{array}{l}\text { Major depressive } \\
\text { disorder (7.56\%) }\end{array}$ & $\begin{array}{l}\text { Road traffic } \\
\text { injury (8.55\%) }\end{array}$ & $\begin{array}{l}\text { Road traffic } \\
\text { injury }(12.40 \%)\end{array}$ & $\begin{array}{l}\text { Major depressive } \\
\text { disorder }(7.88 \%)\end{array}$ & $\begin{array}{l}\text { Road traffic } \\
\text { injury }(8.63 \%)\end{array}$ \\
\hline 2 & $\begin{array}{l}\text { Road traffic } \\
\text { injury (11.04\%) }\end{array}$ & $\begin{array}{l}\text { Congenital } \\
\text { anomalies } \\
(7.65 \%)\end{array}$ & $\begin{array}{l}\text { Road traffic } \\
\text { injury }(7.79 \%)\end{array}$ & $\begin{array}{l}\text { Ischemic heart } \\
\text { disease }(7.38 \%)\end{array}$ & $\begin{array}{l}\text { Preterm birth } \\
\text { complications } \\
(6.94 \%)\end{array}$ & $\begin{array}{l}\text { Preterm birth } \\
\text { complications } \\
(6.38 \%)\end{array}$ & $\begin{array}{l}\text { Ischemic heart } \\
\text { disease }(7.46 \%)\end{array}$ & $\begin{array}{l}\text { Preterm birth } \\
\text { complications } \\
(5.58 \%)\end{array}$ & $\begin{array}{l}\text { Ischemic heart } \\
\text { disease }(6.23 \%)\end{array}$ \\
\hline 3 & $\begin{array}{l}\text { Ischemic heart } \\
\text { disease }(6.03 \%)\end{array}$ & $\begin{array}{l}\text { Major depressive } \\
\text { disorder (5.72\%) }\end{array}$ & $\begin{array}{l}\text { Congenital } \\
\text { anomalies } \\
(6.53 \%)\end{array}$ & $\begin{array}{l}\text { Preterm birth } \\
\text { complications } \\
(6.00 \%)\end{array}$ & $\begin{array}{l}\text { Diabetes mellitus } \\
(4.71 \%)\end{array}$ & $\begin{array}{l}\text { Ischemic heart } \\
\text { disease }(6.12 \%)\end{array}$ & $\begin{array}{l}\text { Diabetes mellitus } \\
(5.79 \%)\end{array}$ & $\begin{array}{l}\text { Diabetes mellitus } \\
(5.10 \%)\end{array}$ & $\begin{array}{l}\text { Major depressive } \\
\text { disorder (5.87\%) }\end{array}$ \\
\hline 4 & $\begin{array}{l}\text { Congenital } \\
\text { anomalies } \\
(5.71 \%)\end{array}$ & $\begin{array}{l}\text { Iron-deficiency } \\
\text { anemia }(3.86 \%)\end{array}$ & $\begin{array}{l}\text { Ischemic heart } \\
\text { disease }(5.09 \%)\end{array}$ & $\begin{array}{l}\text { Low back pain } \\
(5.37 \%)\end{array}$ & $\begin{array}{l}\text { Low back pain } \\
(4.64 \%)\end{array}$ & $\begin{array}{l}\text { Major depressive } \\
\text { disorder (5.61\%) }\end{array}$ & $\begin{array}{l}\text { Low back pain } \\
(5.77 \%)\end{array}$ & $\begin{array}{l}\text { Low back pain } \\
(5.06 \%)\end{array}$ & $\begin{array}{l}\text { Diabetes mellitus } \\
(5.51 \%)\end{array}$ \\
\hline 5 & $\begin{array}{l}\text { Low back pain } \\
(3.88 \%)\end{array}$ & $\begin{array}{l}\text { Ischemic heart } \\
\text { disease }(3.78 \%)\end{array}$ & $\begin{array}{l}\text { Major depressive } \\
\text { disorder }(4.43 \%)\end{array}$ & $\begin{array}{l}\text { Diabetes mellitus } \\
(5.26 \%)\end{array}$ & $\begin{array}{l}\text { Congenital } \\
\text { anomalies } \\
(4.54 \%)\end{array}$ & $\begin{array}{l}\text { Low back pain } \\
(5.08 \%)\end{array}$ & $\begin{array}{l}\text { Preterm birth } \\
\text { complications } \\
(4.79 \%)\end{array}$ & $\begin{array}{l}\text { Ischemic heart } \\
\text { disease }(4.46 \%)\end{array}$ & $\begin{array}{l}\text { Low back pain } \\
(5.48 \%)\end{array}$ \\
\hline 6 & $\begin{array}{l}\text { Major depressive } \\
\text { disorder (3.51\%) }\end{array}$ & $\begin{array}{l}\text { Lower respiratory } \\
\text { infections } \\
(3.69 \%)\end{array}$ & $\begin{array}{l}\text { Low back pain } \\
(3.51 \%)\end{array}$ & $\begin{array}{l}\text { Major depressive } \\
\text { disorder (4.29\%) }\end{array}$ & $\begin{array}{l}\text { Ischemic heart } \\
\text { disease }(4.26 \%)\end{array}$ & $\begin{array}{l}\text { Diabetes mellitus } \\
(5.04 \%)\end{array}$ & $\begin{array}{l}\text { Major depressive } \\
\text { disorder }(4.47 \%)\end{array}$ & $\begin{array}{l}\text { Anxiety disorders } \\
(4.30 \%)\end{array}$ & $\begin{array}{l}\text { Preterm birth } \\
\text { complications } \\
(5.11 \%)\end{array}$ \\
\hline 7 & $\begin{array}{l}\text { Lower respiratory } \\
\text { infections } \\
(2.94 \%)\end{array}$ & $\begin{array}{l}\text { Diarrheal } \\
\text { diseases (3.41\%) }\end{array}$ & $\begin{array}{l}\text { Lower respiratory } \\
\text { infections } \\
(3.26 \%)\end{array}$ & $\begin{array}{l}\text { Cerebrovascular } \\
\text { disease }(3.54 \%)\end{array}$ & $\begin{array}{l}\text { Anxiety disorders } \\
(4.10 \%)\end{array}$ & $\begin{array}{l}\text { Congenital } \\
\text { anomalies } \\
(3.79 \%)\end{array}$ & $\begin{array}{l}\text { Cerebrovascular } \\
\text { disease }(3.46 \%)\end{array}$ & $\begin{array}{l}\text { Iron deficiency } \\
\text { anemia }(3.75 \%)\end{array}$ & $\begin{array}{l}\text { Cerebrovascular } \\
\text { disease }(3.44 \%)\end{array}$ \\
\hline 8 & $\begin{array}{l}\text { Cerebrovascular } \\
\text { disease }(2.77 \%)\end{array}$ & $\begin{array}{l}\text { Road traffic } \\
\text { injury (3.28\%) }\end{array}$ & $\begin{array}{l}\text { Iron deficiency } \\
\text { anemia }(3.09 \%)\end{array}$ & $\begin{array}{l}\text { Congenital } \\
\text { anomalies } \\
(3.28 \%)\end{array}$ & $\begin{array}{l}\text { Iron deficiency } \\
\text { anemia }(3.89 \%)\end{array}$ & $\begin{array}{l}\text { Cerebrovascular } \\
\text { disease } 3.41 \% \text { ) }\end{array}$ & $\begin{array}{l}\text { Drug-use } \\
\text { disorders } \\
(2.75 \%)\end{array}$ & $\begin{array}{l}\text { Congenital } \\
\text { anomalies } \\
(3.48 \%)\end{array}$ & $\begin{array}{l}\text { Congenital } \\
\text { anomalies } \\
(2.97 \%)\end{array}$ \\
\hline 9 & $\begin{array}{l}\text { Neonatal } \\
\text { encephalopathy } \\
(2.62 \%)\end{array}$ & $\begin{array}{l}\text { Cerebrovascular } \\
\text { disease }(3.27 \%)\end{array}$ & $\begin{array}{l}\text { Cerebrovascular } \\
\text { disease }(2.98 \%)\end{array}$ & $\begin{array}{l}\text { Drug-use } \\
\text { disorders } \\
(2.31 \%) \\
\end{array}$ & $\begin{array}{l}\text { Road traffic } \\
\text { injury }(3.48 \%)\end{array}$ & $\begin{array}{l}\text { Iron deficiency } \\
\text { anemia }(2.81 \%)\end{array}$ & $\begin{array}{l}\text { Congenital } \\
\text { anomalies } \\
(2.62 \%)\end{array}$ & $\begin{array}{l}\text { Cerebrovascular } \\
\text { disease }(3.41 \%)\end{array}$ & $\begin{array}{l}\text { Anxiety disorders } \\
(2.88 \%)\end{array}$ \\
\hline 10 & $\begin{array}{l}\text { Diabetes mellitus } \\
(2.62 \%)\end{array}$ & $\begin{array}{l}\text { Low back pain } \\
(3.00 \%)\end{array}$ & $\begin{array}{l}\text { Diarrheal } \\
\text { diseases (2.86\%) }\end{array}$ & $\begin{array}{l}\text { Iron deficiency } \\
\text { anemia (2.08\%) }\end{array}$ & $\begin{array}{l}\text { Cerebrovascular } \\
\text { disease (3.22\%) }\end{array}$ & $\begin{array}{l}\text { Anxiety disorders } \\
(2.77 \%)\end{array}$ & $\begin{array}{l}\text { Iron deficiency } \\
\text { anemia }(1.92 \%)\end{array}$ & $\begin{array}{l}\text { Road traffic } \\
\text { injury (3.20\%) }\end{array}$ & $\begin{array}{l}\text { Iron deficiency } \\
\text { anemia }(2.67 \%)\end{array}$ \\
\hline
\end{tabular}

The opinions expressed by authors contributing to this journal do not necessarily reflect the opinions of the U.S. Department of Health and Human Services, the Public Health Service, the Centers for Disease Control and Prevention, or the authors' affiliated institutions. 
Table 3. Leading Risk Factors Attributable to Disability-Adjusted Life Years by Sex, Kingdom of Saudi Arabia, 1990, 2005, and 2010

\begin{tabular}{|c|c|c|c|c|c|c|c|c|c|}
\hline \multirow[b]{2}{*}{ Rank } & \multicolumn{3}{|c|}{1990} & \multicolumn{3}{|c|}{2005} & \multicolumn{3}{|c|}{2010} \\
\hline & Male (\%) & Female (\%) & Total (\%) & Male (\%) & Female (\%) & Total (\%) & Male (\%) & Female (\%) & Total (\%) \\
\hline 1 & $\begin{array}{l}\text { Dietary risks } \\
(4.49 \%)\end{array}$ & $\begin{array}{l}\text { Dietary risks } \\
(2.27 \%)\end{array}$ & $\begin{array}{l}\text { Dietary risks } \\
(6.76 \%)\end{array}$ & $\begin{array}{l}\text { Dietary risks } \\
(6.44 \%)\end{array}$ & $\begin{array}{l}\text { Elevated BMI } \\
(3.98 \%)\end{array}$ & $\begin{array}{l}\text { Elevated BMI } \\
(10.20 \%)\end{array}$ & $\begin{array}{l}\text { Elevated BMI } \\
(7.02 \%)\end{array}$ & $\begin{array}{l}\text { Elevated BMI } \\
(4.61 \%)\end{array}$ & $\begin{array}{l}\text { Elevated BMI } \\
(11.64 \%)\end{array}$ \\
\hline 2 & $\begin{array}{l}\text { Elevated blood } \\
\text { pressure }(3.64 \%)\end{array}$ & $\begin{array}{l}\text { Elevated blood } \\
\text { pressure }(2.27 \%)\end{array}$ & $\begin{array}{l}\text { Elevated blood } \\
\text { pressure (5.91\%) }\end{array}$ & $\begin{array}{l}\text { Elevated BMI } \\
(6.22 \%)\end{array}$ & $\begin{array}{l}\text { Elevated FPG } \\
(2.90 \%)\end{array}$ & $\begin{array}{l}\text { Dietary risks } \\
(9.25 \%)\end{array}$ & $\begin{array}{l}\text { Dietary risks } \\
(6.64 \%)\end{array}$ & $\begin{array}{l}\text { Elevated FPG } \\
(3.28 \%)\end{array}$ & $\begin{array}{l}\text { Dietary risks } \\
(9.68 \%)\end{array}$ \\
\hline 3 & $\begin{array}{l}\text { Elevated BMI } \\
(2.96 \%)\end{array}$ & $\begin{array}{l}\text { Elevated BMI } \\
(2.17 \%)\end{array}$ & $\begin{array}{l}\text { Elevated BMI } \\
(5.13 \%)\end{array}$ & $\begin{array}{l}\text { Elevated FPG } \\
(5.63 \%)\end{array}$ & $\begin{array}{l}\text { Dietary risks } \\
(2.81 \%)\end{array}$ & $\begin{array}{l}\text { Elevated FPG } \\
(8.53 \%)\end{array}$ & $\begin{array}{l}\text { Elevated FPG } \\
(6.25 \%)\end{array}$ & $\begin{array}{l}\text { Dietary risks } \\
(3.04 \%)\end{array}$ & $\begin{array}{l}\text { Elevated FPG } \\
(9.53 \%)\end{array}$ \\
\hline 4 & $\begin{array}{l}\text { Elevated FPG } \\
(2.59 \%)\end{array}$ & $\begin{array}{l}\text { Iron deficiency } \\
\text { anemia }(1.67 \%)\end{array}$ & $\begin{array}{l}\text { Elevated FPG } \\
(4.05 \%)\end{array}$ & \begin{tabular}{|l|} 
Elevated blood \\
pressure (4.99\%)
\end{tabular} & $\begin{array}{l}\text { Elevated blood } \\
\text { pressure } \\
(2.47 \%)\end{array}$ & $\begin{array}{l}\text { Elevated blood } \\
\text { pressure (7.46\%) }\end{array}$ & $\begin{array}{l}\text { Elevated blood } \\
\text { pressure (5.19\%) }\end{array}$ & $\begin{array}{l}\text { Elevated blood } \\
\text { pressure } \\
(2.64 \%)\end{array}$ & $\begin{array}{l}\text { Elevated blood } \\
\text { pressure }(7.83 \%)\end{array}$ \\
\hline 5 & $\begin{array}{l}\text { Ambient air } \\
\text { pollution }(2.36 \%)\end{array}$ & $\begin{array}{l}\text { Elevated FPG } \\
(1.46 \%)\end{array}$ & $\begin{array}{l}\text { Ambient air } \\
\text { pollution (3.78\%) }\end{array}$ & $\begin{array}{l}\text { Physical inactivity } \\
(3.32 \%)\end{array}$ & $\begin{array}{l}\text { Physical } \\
\text { inactivity } \\
\text { (1.66\%) }\end{array}$ & $\begin{array}{l}\text { Physical inactivity } \\
(4.98 \%)\end{array}$ & $\begin{array}{l}\text { Physical inactivity } \\
(3.51 \%)\end{array}$ & $\begin{array}{l}\text { Physical } \\
\text { inactivity } \\
(1.82 \%)\end{array}$ & $\begin{array}{l}\text { Physical inactivity } \\
(5.33 \%)\end{array}$ \\
\hline 6 & Smoking (1.65\%) & $\begin{array}{l}\text { Ambient air } \\
\text { pollution (1.42\%) }\end{array}$ & $\begin{array}{l}\text { Iron deficiency } \\
\text { anemia (3.14\%) }\end{array}$ & $\begin{array}{l}\text { Ambient air } \\
\text { pollution }(2.77 \%)\end{array}$ & $\begin{array}{l}\text { Iron deficiency } \\
\text { anemia }(1.59 \%)\end{array}$ & $\begin{array}{l}\text { Ambient air } \\
\text { pollution (4.02\%) }\end{array}$ & $\begin{array}{l}\text { Ambient air } \\
\text { pollution }(2.77 \%)\end{array}$ & $\begin{array}{l}\text { Iron deficiency } \\
\text { anemia }(1.55 \%)\end{array}$ & $\begin{array}{l}\text { Ambient air } \\
\text { pollution (4.05\%) }\end{array}$ \\
\hline 7 & $\begin{array}{l}\text { Occupational } \\
\text { risks (1.61\%) }\end{array}$ & $\begin{array}{l}\text { Suboptimal } \\
\text { breastfeeding } \\
(0.95 \%)\end{array}$ & Smoking (2.40\%) & Smoking (2.11\%) & $\begin{array}{l}\text { Ambient air } \\
\text { pollution } \\
(1.25 \%)\end{array}$ & $\begin{array}{l}\text { Iron deficiency } \\
\text { anemia }(2.82 \%)\end{array}$ & Smoking (2.49\%) & $\begin{array}{l}\text { Ambient air } \\
\text { pollution } \\
(1.27 \%)\end{array}$ & Smoking (3.02\%) \\
\hline 8 & $\begin{array}{l}\text { Iron deficiency } \\
\text { anemia }(1.47 \%)\end{array}$ & $\begin{array}{l}\text { Household air } \\
\text { pollution }(0.92 \%)\end{array}$ & $\begin{array}{l}\text { Household air } \\
\text { pollution (2.23\%) }\end{array}$ & $\begin{array}{l}\text { Occupational } \\
\text { risks (1.88\%) }\end{array}$ & $\begin{array}{l}\text { Elevated total } \\
\text { cholesterol } \\
(0.72 \%)\end{array}$ & Smoking (2.79\%) & $\begin{array}{l}\text { Occupational } \\
\text { risks (1.91\%) }\end{array}$ & $\begin{array}{l}\text { Intimate partner } \\
\text { violence } \\
(0.73 \%)\end{array}$ & $\begin{array}{l}\text { Iron deficiency } \\
\text { anemia }(2.68 \%)\end{array}$ \\
\hline 9 & $\begin{array}{l}\text { Elevated total } \\
\text { cholesterol } \\
(1.47 \%)\end{array}$ & $\begin{array}{l}\text { Childhood } \\
\text { underweight } \\
(0.87 \%)\end{array}$ & $\begin{array}{l}\text { Elevated total } \\
\text { cholesterol } \\
(2.23 \%)\end{array}$ & $\begin{array}{l}\text { Elevated total } \\
\text { cholesterol } \\
(1.49 \%)\end{array}$ & $\begin{array}{l}\text { Smoking } \\
(0.68 \%)\end{array}$ & $\begin{array}{l}\text { Elevated total } \\
\text { cholesterol } \\
(2.21 \%)\end{array}$ & $\begin{array}{l}\text { Drug-use } \\
\text { disorders (1.66\%) }\end{array}$ & $\begin{array}{l}\text { Elevated total } \\
\text { cholesterol } \\
(0.66 \%)\end{array}$ & $\begin{array}{l}\text { Drug-use } \\
\text { disorders (2.24\%) }\end{array}$ \\
\hline 10 & $\begin{array}{l}\text { Household } \\
\text { pollution (1.31\%) }\end{array}$ & $\begin{array}{l}\text { Elevated total } \\
\text { cholesterol } \\
(0.76 \%)\end{array}$ & $\begin{array}{l}\text { Suboptimal } \\
\text { breastfeeding } \\
(1.83 \%)\end{array}$ & \begin{tabular}{|l|} 
Drug-use \\
disorders (1.41\%)
\end{tabular} & $\begin{array}{l}\text { Intimate partner } \\
\text { violence } \\
(0.65 \%)\end{array}$ & $\begin{array}{l}\text { Occupational } \\
\text { risks }(2.01 \%)\end{array}$ & $\begin{array}{l}\text { Elevated total } \\
\text { cholesterol } \\
(1.32 \%)\end{array}$ & $\begin{array}{l}\text { Drug-use } \\
\text { disorders } \\
(0.58 \%)\end{array}$ & $\begin{array}{l}\text { Occupational } \\
\text { risks }(2.05 \%)\end{array}$ \\
\hline
\end{tabular}

Abbreviations: BMI, body mass index; FPG, fasting plasma glucose.

The opinions expressed by authors contributing to this journal do not necessarily reflect the opinions of the U.S. Department of Health and Human Services, the Public Health Service, the Centers for Disease Control and Prevention, or the authors' affiliated institutions. 


\section{Appendix. Recommendations from the Riyadh Declaration}

Following deliberations and debates, experts gathered at the International Conference on Healthy Lifestyles and Non-communicable Diseases (NCDs) in the Arab World and the Middle East, held in Riyadh, Kingdom of Saudi Arabia, in September 2012, recommended the following immediate action points:

1. An annual screening package for early components of the metabolic syndrome (pre-hypertension, pre-diabetes, overweight, tobacco addiction) should be available to all asymptomatic adults from age 25 years, through primary health care facilities, fully or largely subsidized based on the health insurance system and available finances in each country.

2. Individuals diagnosed through the screening package should be referred to adequate and accessible care.

3. Schools must be recognized as a major venue for NCD prevention. Accreditation or rehabilitation of educational facilities for boys and girls should be based on the criteria of World Health Organization Health Promoting Schools. In particular, physical education and access to healthy food items should be considered as priorities in the educational system, equal in importance to reading and writing.

4. Urban planning licenses of new residential developments have to include environments that promote walking or biking, social gathering, and safe space to allow physical activity for women, elderly persons, and children.

5 . Adopt the mandatory use of traffic light signs on all industrial food items imported or locally manufactured.

6. Impose nutritional labeling on all fast food items.

7. Impose the sale of fresh fruits and vegetables as well as low-calorie products in all vending venues where high-calorie equivalents are sold.

8. Require a gradual reduction over the coming 5 years of the salt content of all manufactured food items, to ultimately reach $50 \%$ of the initial content.

9. Ban all shisha smoking cafes from residential areas and neighborhoods with health or educational facilities.

10. Increase the taxation on items with negative health effects (tobacco products, energy drinks), and earmark obtained funds to NCD programs.

The opinions expressed by authors contributing to this journal do not necessarily reflect the opinions of the U.S. Department of Health and Human Services, the Public Health Service, the Centers for Disease Control and Prevention, or the authors' affiliated institutions. 